\title{
A synopsis of burrowing bugs of Puerto Rico with description of new species Melanaethus wolcotti (Heteroptera: Cydnidae) ${ }^{1,2}$
}

\author{
Richard C. Froeschner" and Jenaro Maldonado-Capriles"
}

\begin{abstract}
This study presents keys to the six genera and 11 species of the hemipterous family Cydnidae, including the new species Melanaethus wolcotti, known to occur in Puerto Rico and a synonymic list of those 11 species with literature and new records.
\end{abstract}

RESUMEN

Sinopsis de las chinches escarbadoras de Puerto Rico con una descripción de la nueva especie Melanaethus wolcotti

Los autores presentan claves para los seis géneros y 11 especies de la familia Cydnidae, de Heteroptera, incluyendo la descripción de la especie nueva Melanaethus wolcotti, que ocurren en Puerto Rico. Se señalan las sinonimias correspondientes y se añaden nuevos registros $I$ ocales.

\section{DISCUSSION}

Among the specimens of Heteroptera assembled by the junior author in his continuing efforts to make better known the insect fauna of Puerto Rico were six specimens of the new species of the burrowing bug described below. We take this opportunity also to present a synopsis, a literature catalog, and new distribution records for the Cydnidae (sensu Froeschner, 1960) of Puerto Rico.

\section{Melanaethus wolcotti new species}

Figs. 1-3

Diagnosis: In Froeschner's (1960:424-425) key to members of the genus Melanaethus this species runs to $M$. cubensis (Barber and Bruner)

'Manuscript submitted to Editorial Board 16 August 1991.

2The authors thank Thomas J. Henry, Systematic Entomology Laboratory, U. S. Department of Agriculture, c/o National Museum of Natural History, Washington, D. C., and Paul J. Spangler, Department of Entomology, National Museum of Natural History, Washington, D. C., for helpful reviews of the manuscript.

"Entomologist, National Museum of Natural History -NHB 105, Smithsonian Institution, Washington, D. C. 20560.

${ }^{4}$ Entomologisl, Urb. Aponte 6 I 1, Cayey, Puerto Rico 00736 and Department of Crop Protection. 

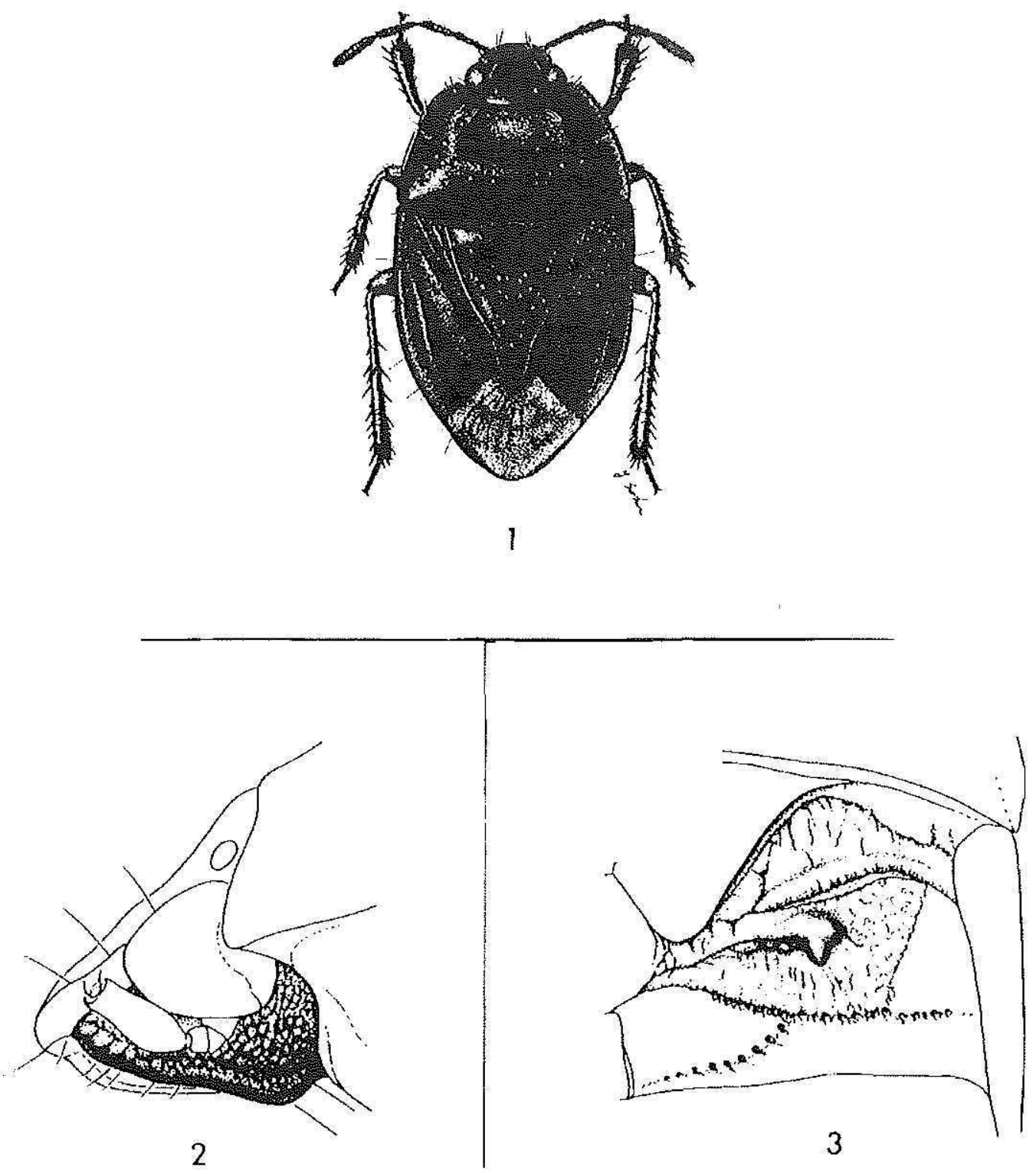

FIG. 1.-Melanaethus wolcotti, new species, dorsal view, natural length $5.4 \mathrm{~mm}$

Fig. 2.-Same, lateral view of head

Fig. 3.- Same, meso- and metapleura

from which it differs in both sexes by the buccula (fig. 2) posteriorly being high and abruptly terminated (evanescent in $M$. cubensis); in the male (only) having the anterior pronotal lobe (fig. 1) discally with a strongly impressed area nearly as wide as the head across both eyes (not impressed in male of $M$. cubensis).

Description of holotype (measurements in $\mathrm{mm}$ ): Elongate oval; length, 5.47 ; greatest width, 2.90 . 
Head: Length, 0.87; width, 1.90; interocular width, 0.69; anterior outline a slightly flattened semicircle; margin thickly calloused, dorsal "carina" distinctly submarginal; surface somewhat flattened, shining, subalutaceous; clypeus as long as juga, finely transversely wrinkled; jugum with several low course rugae radiating outward from base of clypeus; ocellus large, separated from nearest eye by a space equal to ocellar width; maxillary plate (fig. 2) shining, coarsely punctate ventrally and posteriorly. Antennal segments: I, 0.23; II, 0.36; III, 0.39; IV, 0.39; $\mathrm{V}, 0.59$. Buccula as high as labial segment II, gradually elevating posteriorly, then convexly and abruptly terminated. Labium reaching between middle coxae; segments: I, 0.47; II, 0.71; III, 0.56; IV, 0.36 .

Pronotum: Length slightly more than half width, 1.41:2.77; anterior margin strongly concave; lateral margins converging from base, more abruptly and convexly so in anterior third, with 4 widely spaced, very feeble setigerous punctures submarginally; transverse impression obsolete, indicated by an irregular row of coarse punctures; anterior lobe (fig. 1) discally with a prominent concavity about as wide as width of head across both eyes, anteriorly with a submarginal row of coarse punctures across middle third; disc of posterior lobe impunctate.

Scutellum: Longer than wide, $1.96: 1.79$; dise shining, with sparsely and irregularly spaced punctures slightly coarser than those marking transverse suture of pronotum.

Hemelytron: Clavus and corium very finely alutaceous; clavus with 1 row of punctures becoming obsolete about midlength; corium with 1 complete row of fine punctures paralleling claval suture and basal half of a second row of much coarser punctures; costa convex with a single setigerous puncture subbasally; coriomembranal suture weakly concave for full width; membrane as long as broad, reaching apex of genital segment.

Propleuron: Both convexities impunctate; prosternal carina about half as high as labial segment Ir.

Mesopleuron: Lateral polished area impunctate.

Metapleuron: Polished posteriorly projecting lobe (fig. 3) of peritreme small, triangular posteriorly, removed from lateral margin of dull evaporative area by a space nearly twice the width of the lobe; lateral polished area impunctate.

Legs: Anterior tibia with 5-6 strong spines in dorsolateral row.

Sternites: Weakly alutaceous; impunctate.

Terminalia: Genital capsule weakly alutaceous, impunctate, apical margin straight except for very shallow emargination medially.

Type data: Holotype, male (fig. 1), labeled "Puerto Rico, Toa Baja, June 1984, Rd.2 km 21, Santiago Blay" (in U. S. National Museum of Natural History). Paratypes: 4, 1, with same data as holotype (in Maldonado Collection and U. S. National Museum). 
Comments: The female is generally similar to the male but lacks the concavity on the anterior pronotal lobe.

The paratypes show no significant differences from the above description except that one of them has a second costal setigerous puncture on both sides just before the midlength of the costa. On all specimens the seta arising from each costal puncture is quite small.

This new species is structurally so similar to another Greater Antillean species, $M$. cubensis, that one may surmise they were derived from the same ancestral form. The modification of the anterior prontal lobe [male with a deep, wide concavity and female without] is suggestive of $M$. cavicollis (Blatchley) - known only from the southeastern United States - which differs from $M$. wolcotti in having numerous distinct punctures laterally on both prontal lobes, along the full length of the exocorium, over most of the anterior propleural convexity.

Keys to the genera and species of Cydnidae in Puerto Rico

1. Coria meeting in a short straight line beyond apex of scutellum ........ Subfamily Amnestinae. ........ Amnestus Dallas Coria not meeting beyond apex of scutellum. . . . . . . Subfamily Cydninae 2

2. Pronotum with a sharp, deeply incised, subapical line paralleling anterior margin from side to side ..................... Pangaeus Stål Pronotum without an impressed subapical line .................. 3

3. Jugurn with a complete submarginal row [from eye to apex of jugum] of close set setigerous punctures giving rise to long hairs, or short blunt pegs or both Jugum with submarginal punctures, at least in part, widely separated from each other and giving rise to long hairs but no blunt pegs

4. Dull evaporative area on metapleuron for virtually full width interrupted anteriorly by an elevated, polished strip

Rhytidoporus Uhler

Dull evaporative area on metapleuron not so interrupted Tominotus Mulsant and Rey

5. Peritreme [cuticular modification associated with scent gland opening] with a small polished triangular or semicircular posterior projection ........................................... Melanaethus Uhler Peritreme without a polished posterior projection (sometimes with a small, curved spine) Dallasiellus Berg

Subfamily Amnestinae Hart

Genus Amnestus Dallas

1. Jugum with 5 marginal tubercles

Jugum with 4 marginal tubercles 
J. Agric. Univ. P.R. VOL. 76, N(). 3-4, JUL X/OCCOBE: 1992181

2. Prosternal carinae (in profile) at anterior end rising vertically to prominent angulation, thence evanescent posteriorly. Corium without longitudinal brown line. Jength, $1.6-2.3 \mathrm{~mm}$

subferrugineus (Westwood)

Prosternal carinae (in profile) rounded, anterior end neither abruptly rising or angulate. Corium discally with a longitudinal brown line that bends laterally along apical margin. Length, $2.2-2.4 \mathrm{~mm}$

radialis Froeschner

3. Clypeus with prominent transverse rugae. Corium with obscure fuscous cloud across middle and apex. Length 1.7-1.9 mm

diminuatus Barber

Clypeus not transversely rugose. Corium without dark markings. Length $1.8-2.0 \mathrm{~mm}$ pusio Stål

\section{Subfamily Cydninae \\ Genus Melanaethus Uhler}

1. Shining posterior projection of peritreme large, almost semicircular, reaching almost to side margin of dull evaporative area. Length,

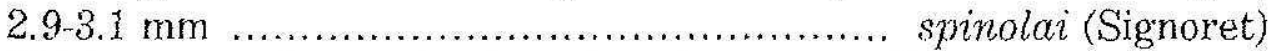
Shining posterior projection of peritreme small, triangular, separated from lateral margin of dull evaporative area by a space nearly twice the diameter of the lobe. Length more than $5 \mathrm{~mm}$.......... 2

2. Buccula gradually higher to posterior end, there higher than diameter of antennal segment II, then abruptly terminated. Male with a large discal impression (virtually as wide as head across both eyes) on anterior pronotal lobe. Length, $5.4-5.6 \mathrm{~mm}$

wolcotti Froeschner and Maldonado

Buccula becoming evanescent posteriorly, height less than diameter of antennal segment II. Male without a discal impression on anterior pronotal lobe. Length, $5.3 \mathrm{~mm}$....... cubensis (Barber and Bruner)

\section{Genuis Pangaeus Stål}

Mesopleural dull area extending uninterrupted to posterior margin and into posterolateral angle of supporting sclerite. Margin of head and costa each with 1 submarginal setigerous puncture. Male with posteroventral margin of posterior tibia having only 4 spines and no subbasal angulation. Length (male only), 4.2-5.1 $\mathrm{mm}$............ piceatus Stål

\section{Genus Rhytidoporus Uhler}

Ocelli present. Prontum laterally with submarginal row of 5-6 setigerous punctures. Anterior pronotal lobe subapically with a transverse row of fewer than 10 punctures between setigerous punctures. Length, $3.8-5.8 \mathrm{~mm}$ indentatus Uhler 
Genus Tominotus Mulsant and Rey

Scutellar apex narrow, its width at level of inner apical angles of coria distinctly less than half the coriomembranal suture. Dorsum highly polished. Length, 5.1-7.2 mm communis (Uhler)

Records of Cydnidae for Puerto Rico

[All citations, except for those from original descriptions, include only the Puerto Rican records]

Subfamily Amnestinae Hart

Genus Amnestus Dallas

Amnestus diminuatus Barber

Amnestus "sp. nov." Wolcott, 1936:181 [Adjuntas].

Amnestus diminuatus Barber, 1939:274 [new species-- Puerto Rico: Adjuntas]. - Wolcott, 1950:190 [Adjuntas]. - Froeschner, 1960:643 [Adjuntas].

Amnestus pusio (Stå)

Magoa pusio Stål, 1860:14 [new species-Brazil].

Amnestus pusio.- Barber, 1923:12 [Puerto Rico]; 1939:274 [Isabela; Puerto Real, Vieques Island]. - Blatchley, 1926:89 [Puerto Rico].Wolcott, 1936:181 (Bayamón]; 1950:189 [Puerto Rico].- Ruckes, 1952:4 [Puerto Rico].- Froeschner, 1960:654 [Isabela; Ponce].

Amnestus pusillus.- Gundlach, 1894:276 [F. Puerto Riquena].- Wolcott, 1924a:256 [Puerto Rico]. [Correction of these 2 misidentifications was made by Wolcott, 1950:189]

Amnestus radialis Froeschner

Amnestus radialis Froeschner, 1960:656 [new species- Island of Martinique]; 1981:51 [Puerto Rico].

Amnestus sexdentatus Froeschner, 1960:657 [new species- Puerto Rico: Ponce].- Maldonado and Navarro, 1967:49 [Puerto Rico]. Synonymized by Froeschner, 1981:51.

New Records: Aguas Buenas (in guano in Aguas Buenas Cave), S. and J. Peck. $3.5 \mathrm{~km}$ s Cabo Rojo (Cueva Tuna, nymphs only), S. and J. Peck. Aguas Buenas, B267, Aguas Buenas Cave, 7-17, v. 73, $250 \mathrm{~m}$, S. Peck et al.

Amnestus subferrugineus (Westwood)

Cydnus subferrugineus westwood, 1837:19 [new species- Island of St. Vincent].

Amnestus subfermigineus.-- Barber, 1923:12 [Puerto Rico]; 1939:273 [Adjuntas; Cayey]. - Wolcott, 1950:190 [Puerto Rico, "all . . . from the mountains"). 
J. Agric. Univ. P.R. vol. 76, No. 3-4, JULy/OCTOBER, 1992183

Subfamily Cydninae Billberg

Genus Dallasiellus Berg

Dallasiellus lugubrius (Stål)

Aethus lugubris Stål, 1860:13 [new species--Brazil].

Geocnethus reversus Barber and Bruner, 1932:237 [new speciesPuerto Rico: Isabela; Mayagüez (holotype); Río Piedras. Cuba].Wolcott, 1936:181 [Isabela; Mayagüez; Río Piedras].- Barber, 1939:272 [Isabela; Mayagüez; Río Piedras].- Synonymized by Froeschner, 1960:613.

Dallasiellus lugubris.- Froeschner, 1960:613 [Gurabo; Mayagüez; Río Piedras; Vieques].- Maldonado and Navarro, 1967:49 [Puerto Rico].

Genus Melanaethus Uhler

Melanaethus cubensis (Barber and Bruner)

Geocnethus cubensis Barber and Bruner, 1932:236 [new speciesCuba].- Wolcott, 1950:189 [Mayagüez].

Note: Present combination made by Froeschner, 1960:432.

Melanaethus spinolai (Signoret)

Aethus spinolae (sic) Signoret, 1863:545 [new species-Chile].

Geotomus spinolai.- Wolcott, 1950:189 [Fajardo; Humacao].

Melanaethus wolcotti Froeschner and Maldonado, new species

Melanaethus wolcotti Froeschner and Maldonado, described and recorded above.

\section{Genus Pangaeus Stål}

Pangaeus piceatus Stål

Pangaeus piceatus Stål, 1862:96 [new species- Mexico].- Froeschner, 1960:492 [Ponce].- Maldonado and Navarro, 1967:49 [Puerto Rico].

\section{Genus Rhytidoporus Uhler}

Rhytidoporus indentatus Uhler

Rhytidoporus indentatis Uhlex, 1877:380 [new species-Cuba. United States of America].

Rhytidiporus (sic) indentatus.— Wolcott, 1924a:256 [Manatí]; 1924b:12 [Pt. Cangrejos].

Aethus indentatus. - Barber, 1923:12 [Puerto Rico].- Wolcott, 1936:181 [Algarroba, Coamo Springs; Maricao; Mayagüez]. 
Rhytidoporus (Rhytidoporus) indentatus.- Froeschner, 1960:387 [Aguirre; El Yunque].

New records: $15 \mathrm{~km} \mathrm{~s}$. Arecibo (in guano, Cueva Los Chorros), S. and J. Peck; Gurabo; Guavate St. Forrest, July 1987, J. Maldonado; Maricao Forest, July 1987, J. Maldonado; Ramey Air Force Base.

\section{Genus Tominotus Mulsant and Rey}

Tominotus communis (Uhler)

Aethus communis Uhler, 1877:379 [new species-Cuba. United States of America]. - Barber, 1939:271 [Bayamón].- Wolcott, 1950:189 [Bayamón].

Tominotus communis.- Froeschner, 1960:551 [Bayamón]. Maldonado and Navarro, 1967:49 [Puerto Rico].

Note: Wolcott (1950, above) commented that the species had not been taken in Puerto Rico since a specimen was collected at Bayamón in 1899 .

\section{LITERATURE CITED}

Barber, H. G., 1923. A Preliminary Report on the Hemiptera-Heteroptera of Porto Rico Collected by the American Museum of Natural History. Amer. Mus. Novitates, $75: 1-13$.

— 1939. Insects of Porto Rico and the Virgin Islands-Hemiptera-Heteroptera (excepting the Miridae and Corixidae). Sei. Surv. Porto Rico and Virgin Islands, N,Y, Acad. Sci., 14(3): 263-441.

— and S. C. Bruner, 1932. The Cydnidae and Pentatomidae of Cuba. J. Dep. Agric. P.R. 16(3): 231-284, plates 24-26.

Blatchley, W. S., 1926. Heteroptera or True Bugs of Eastern North America. 1116 pages. Indianapolis: The Nature Publishing Co.

Froeschner, R. C., 1960. Cydnidae of the Western Hemisphere. Proceed. U. S. Nat. Mus., 111(3420): 337-680.

_ 1981. Amnestus radialis Froeschner, 1960, Senior synonym of A. sexdentatus Froeschner, 1960 (Hemiptera: Cydnidae). Ent. News, 92: 51.

Gundlach, J., 1894. Hemípteros. In: Apuntes para la Fauna Puerto-Riquena. An. Soc. Española Hist. Nat., '22; 274-287.

Maldonado-Capriles, J. and C. A. Navarro, 1967. Additions and Corrections to Wolcott's "Insects of Puerto Rico." Carib. J. Sci., 7: 45-64.

Ruckes, H., 1952. Some Scutelleroid Hemiptera of the Bahama Islands, British West Indies. Amer. Mus. Novitates, 1591: 1-9.

Signoret, V., 1863. Revision des Hémiptères du Chili. Ann. Soc. Ent. France, series 4, 3: $541-588$, plates $11-13$.

Stål, C., 1860. Bidrag till Rio Janerio-Traktens Hemipter-Fauna. Kongl. Svenska Vet.Akad. Handl., 2(7): 1-84.

- 1862 . Hemiptera Mexicana enumeravit speciesque nova descripsit. Stett. Eng. Zeitg., 23(1-3): 273-281, (4-6): 289-325, (11-12): 437-462.

Uhler, P. R., 1877. Report on the Insects Collected by P. R. Ubler during the Explorations of 1875, Including Monographs of the Families Cydnidae and Saldidae, and the Hemiptera Collected by A. S. Packard, Jr, M. D. Bull, U. S. Geol. Geogr. Surv. Territ. 3: $355-475,765-801$, plates $27-28$. 
J. Agrie. Univ. P.R. VOL. 76, NO. 3-4, JULY/OCTOBER, 1992185

Westwood, J. O., 1837. A Catalogue of Hemiptera in the Collection of the Rev. F. W. Hope, with Short Latin Descriptions of New Species. 1: 1-46. London: J. $1 \therefore$ Bridgewater.

Wolcott, G. W. 1924. Insectae Portoricensis, A Preliminary Annotated Check-List of the Insects of Porto Rico, with Descriptions of Some New Species. J. Dep. Agric. P.R. 7: [4] 1-313 (1923).

—, 1924. The Food of Porto Rican Lizards. J. Dep. Agric. P.R. 7(4): 5-37.

- 1924. First Supplement to "Insectae Portoricen.is." J. Dep. Agric. P. R., 7(4): 38-43.

__-, 1936. "Insectae Borinquenses" a Revised checklist of the Insects of Puerto Rico, with Host-Plant Index by J. I. Otero. J. Agric.. Univ. P.R., 20: i-ii, 1-627 [i-iii].

- 1950. The Insects of Puerto Rico. J. Agrie, Univ. P.R., 32: 1-224 (1948-note on p. 224 reads, "Actual date of Publication: September 1, 1950). 